1 Supplemental Material-Appendices

2 Responsible innovation in biotechnology: Stakeholder attitudes and implications for 3 research policy

5 Pat Roberts ${ }^{\mathrm{a}, \mathrm{b}}$, Joseph Herkert ${ }^{\mathrm{b}}$, and Jennifer Kuzma ${ }^{\mathrm{a}, \mathrm{b}^{*}}$

$6 \quad{ }^{\mathrm{a}}$ School of Public and International Affairs, North Carolina State University, NC, US

$7 \quad$ benetic Engineering and Society Center, North Carolina State University, NC, US

8 Corresponding Author: jkuzma@ncsu.edu

\title{
List of contents:
}

Table A1. Participant demographics

Table A2. Focus group discussion questions

Table A3. Handout to participants prior to question 7 in focus groups

Table A4. Survey results: RI principle

Table A5. Survey results on RI policy implementation

$(26$

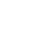




\begin{tabular}{|c|c|c|c|c|c|}
\hline & \multicolumn{5}{|l|}{ Group } \\
\hline & Academe & Industry & Government & $\begin{array}{l}\text { Trade } \\
\text { Organizations }\end{array}$ & $\begin{array}{l}\text { Consumer } \\
\text { Organizations }\end{array}$ \\
\hline Observations & 26 & 30 & 15 & 19 & 14 \\
\hline \multicolumn{6}{|l|}{ Gender } \\
\hline Male & 19 & 20 & 10 & 14 & 6 \\
\hline Female & 7 & 10 & 5 & 5 & 8 \\
\hline \multicolumn{6}{|l|}{ Race } \\
\hline Hispanic or Latino & & 1 & & & \\
\hline White & 23 & 25 & 11 & 19 & 13 \\
\hline African American & & 2 & 1 & & \\
\hline Asian & 2 & 3 & 3 & & \\
\hline Two or more races & 1 & & & & 1 \\
\hline Age & $46.1(10.45)$ & $53.5(8.83)$ & $53.6(11.52)$ & $54.4(11.87)$ & $42.7(14.34)$ \\
\hline \multicolumn{6}{|l|}{ Education } \\
\hline $\begin{array}{l}\text { High school degree } \\
\text { (or GED) }\end{array}$ & & & & & 1 \\
\hline \multicolumn{6}{|l|}{ Some college } \\
\hline Bachelor's degree & 1 & 3 & 2 & 4 & 6 \\
\hline Master's degree & 1 & 2 & 5 & 6 & 5 \\
\hline Professional degree & 2 & & & 2 & \\
\hline Doctoral degree & 22 & 25 & 8 & 7 & 2 \\
\hline
\end{tabular}


1. What comes to mind when you hear the phrase "Responsible Innovation"? Please write down three words or short phrases.

2. What do you think is an example of innovating in a responsible way? Please describe.

3. What do you think is most important for innovating in a responsible way for genetic engineering (or biotechnology)?

4. Genetically engineered insects are being developed to control agricultural pests. For example, insects engineered to be sterile can be used to reduce population size (see figure a), or insects engineered to be incapable of transmitting plant diseases can be used to replace wild populations (see figure b). What should developers do to responsibly innovate in these cases?

5. What does your organization do to encourage responsibility in innovating or its work more generally (in GE or biotechnology, or alternatively in the affiliated areas like forestry, farming, toxicology, management, policy, etc.)?

6. What comes to mind when you hear the word "ethics"?

7. Here are some key elements of RI from the perspective of social scientists who study emerging technologies: We are not suggesting that these are right or wrong, or recommending them. But we'd like to know what you think about them. Take some time to read examples of these elements: What do you think of these definitions and elements of RI? 


\section{Table A3. Handout to participants prior to question 7 in focus groups}

\section{Handout on RI from social science literature}

Adapted from Stilgoe,J. et al. (2013). Developing a framework for responsible innovation. Research Policy, 42,1568-1580

\section{What is responsible research and innovation?}

"Responsible innovation means taking care of the future through collective stewardship of science and innovation in the present."

"Responsible Research and Innovation (RRI) is a transparent, interactive process by which societal actors and innovators become mutually responsive to each other with a view on the (ethical) acceptability, sustainability, and societal desirability of the innovation process and its marketable products (in order to allow a proper embedding of scientific and technological advances in our society)."

\section{What it means to do RI: The features}

1. Anticipation: Anticipation prompts researchers and organizations to ask 'what if. . .?' questions, to consider contingencies: what is known, what is likely, what is not known, what is plausible, and what is possible, and to consider potential future impacts early in the innovation process.

2. Reflexivity: Reflexivity means holding a mirror up to ones' own activities, positions, biases, and assumptions, and being mindful that a particular framing of an issue may not be universally held.

3. Inclusion (aka Participation): Inclusion is to involve different actors and stakeholders (developers, end-users, policy-makers, and publics) in the discussion about a specific technological-development pathway early on the process.

4. Responsiveness: Responsiveness involves a capacity to change shape or direction in research or innovation in response to stakeholder and public values or to changing circumstances. 
Table A4. Survey results: RI principle

79

\begin{tabular}{llllll}
\hline \multirow{2}{*}{ Group } & \multicolumn{5}{c}{ Principle } \\
\cline { 3 - 5 } Industry & Test iteration & Inclusion & Anticipation & Responsiveness & Reflexivity \\
\hline \multirow{2}{*}{ Government } & Pretest & $4.5(1.8)$ & $6.0(1.2)$ & $4.2(1.7)$ & $6.1(0.9)$ \\
& Posttest & $4.0(1.7)$ & $5.5(1.5)$ & $4.1(1.6)$ & $5.5(1.3)$ \\
\hline Trade & Pretest & $5.4(1.4)$ & $6.6(0.6)$ & $4.7(1.3)$ & $6.1(1.3)$ \\
Organizations & Prettest & $5.8(1.1)$ & $6.0(1.5)$ & $5.2(1.1)$ & $6.5(0.5)$ \\
\hline Consumer & Posttest & $4.7(1.5)$ & $6.3(1.0)$ & $4.8(1.2)$ & $5.7(1.3)$ \\
Organizations & Pretest & $5.3(1.7)$ & $6.6(0.9)$ & $5.0(1.5)$ & $6.3(0.9)$ \\
& Posttest & $6.1(1.3)$ & $6.9(0.3)$ & $6.0(1.0)$ & $6.6(0.7)$ \\
\hline Academe & Pretest & $5.0(1.4)$ & $6.1(0.9)$ & $5.0(1.0)$ & $6.0(1.2)$ \\
& Posttest & $5.3(1.0)$ & $5.9(1.4)$ & $4.5(1.3)$ & $6.0(0.8)$ \\
\hline
\end{tabular}

80

81

82 
83 Table A5. Survey results on RI policy implementation

84

\begin{tabular}{llllll}
\hline \multirow{2}{*}{ Group } & \multicolumn{5}{c}{ Policy Implementation } \\
\cline { 2 - 6 } Industry & Test iteration & Inclusion & Anticipation & Responsiveness & Reflexivity \\
\hline & Pretest & $4.7(1.8)$ & $3.3(1.6)$ & $4.1(1.7)$ & $4.3(1.6)$ \\
\cline { 2 - 6 } Government & Posttest & $4.7(1.6)$ & $3.1(1.7)$ & $3.9(1.6)$ & $4.3(1.7)$ \\
\cline { 2 - 6 } & Pretest & $5.5(1.6)$ & $5.0(1.5)$ & $4.7(1.3)$ & $5.7(1.3)$ \\
\hline \multirow{2}{*}{$\begin{array}{l}\text { Trade } \\
\text { Organizations }\end{array}$} & Posttest & $5.9(1.4)$ & $5.5(1.6)$ & $5.3(1.2)$ & $5.8(1.5)$ \\
\hline Consumer & Pretest & $4.8(1.9)$ & $4.5(1.8)$ & $4.4(1.7)$ & $5.4(1.4)$ \\
\cline { 2 - 6 } Organizations & Posttest & $5.0(1.7)$ & $4.2(2.0)$ & $4.5(1.6)$ & $5.0(1.8)$ \\
\cline { 2 - 6 } Academe & Posttest & $6.4(1.0)$ & $6.3(0.8)$ & $6.1(1.1)$ & $6.6(0.9)$ \\
\cline { 2 - 6 } & Pretest & $5.6(1.0)$ & $5.0(1.5)$ & $4.2(1.7)$ & $5.3(1.7)$ \\
\hline
\end{tabular}

85

86 